\title{
Morphometric Study on the Tibial Collateral Ligament
}

\author{
Estudio Morfométrico del Ligamento Colateral Tibial
}

"Anu Vinod Ranade; "Rajalakshmi Rai; "Latha Venkatraya Prabhu; "*Mangala Kumaran \& ***Arunachalam Kumar

RANADE, A. V.; RAI, R.; PRABHU, L. V.; KUMARAN, M. \& KUMAR, A. Morphometric study on the tibial collateral ligament. Int. J. Morphol., 24(4):677-678, 2006.

SUMMARY: Tibial collateral ligament by virtue of its length, composite attachments, and biomechanical exertions is more prone to lesions. A systematic analysis of the dimensions and variations of this ligament has been presented in this article. With the decrease emphasis on anatomy as a preclinical subject and recent successful moves to curtail total teaching hours for dissection, coupled with the increasing shortage of cadavers, data of this nature will in our opinion becomes scarce progressively. With these factors in context, and attempt is made to record the gross morphological features of the ligament from a series of dissections.

KEY WORDS: Tibial collateral ligament; Anatomy.

\section{INTRODUCTION}

The knee is one of the most commonly injured joints. The stability of the joint is dependant on several muscles, the menisci and four major ligaments. These main ligaments are tibial collateral ligament, fibular collateral ligament, anterior cruciate ligament and posterior cruciate ligament. The tibial collateral ligament of the knee joint is a long triangular band of great strength extending from the medial epicondyle of the femur immediately distal to the adductor tubercle, to be inserted on the upper part of the medial surface of the shaft of tibia (Standring et al., 2005). The ligament has an additional attachment from its deep surface, closer to the posterior border, to the medial meniscus (Standring et $a l$ ). There have been a number of anatomical descriptions of the ligamentous and capsular structures that restrain tibiofibular motion on the medial and posteromedial aspect of the knee (Palmer, 1938; Brantigan \& Voshell, 1943).

The tibial collateral ligament is the most frequently injured ligament of the knee joint (Hammer, 1991). No systematic analysis of the dimensions and variations of this vital ligament have been seriously attempted as yet in Indian literature.

Moreover, with the decreasing emphasis on Anatomy as a preclinical subject and the recent successful moves to curtail teaching hours in dissection (Gross) anatomy coupled with the continuing shortage of cadavers affecting the teaching schedules in most centers, dissection data of this nature presented will in our opinion become scarce progressively. With these factors in context, an attempt is herein made to record the gross morphological features of the ligament.

\section{MATERIAL AND METHOD}

Dissections were performed on lower limbs of 28 cadavers, 24 of which were male cadavers and 4 were female cadavers. The borders and attachments of the tibial collateral ligament were defined and exposed. The lengths of the band from its proximal attachment on the medial epicondyle of the femur to its lower attachment on the tibia were measured to the nearest millimeter.

The breadth of the ligament was measured at two levels, the first just below its femoral end and the other just above its tibial end. In addition to these dimensions (linear), the angle substended by the anterior free border of the ligament to the vertical was recorded using a protractor.

Gross morphological features and variations in the ligament were recorded. All values and data were analyzed.

\footnotetext{
* Department of Anatomy, Kasturba Medical College, Mangalore, Karnataka, India.

** Department of Anatomy, Father Muller's Medical College, Mangalore, Karnataka, India.

**** Department of Anatomy, KS Hegde Medical Academy, Mangalore, Karnataka, India.
} 


\section{RESULTS}

The length of the ligament measured between $97 \mathrm{~mm}$ to $125 \mathrm{~mm}$ (mean $111 \mathrm{~mm}$ ). The proximal breadth was between $9 \mathrm{~mm}$ to $17 \mathrm{~mm}$ (mean $13 \mathrm{~mm}$ ). The distal breadth ranged between 25 $\mathrm{mm}$ to $35 \mathrm{~mm}$ (mean $22.1 \mathrm{~mm}$ ). The obliquity angle ranged between $8^{\circ}$ to $22^{\circ}$ (mean $16.5^{\circ}$ ).

Two out of 28 cadavers dissected showed variations in the shape of the tibial collateral ligament. The proximal attachment in these cases was forked, each limb of the bifurcated attachment being $12 \mathrm{~mm}$ to $13 \mathrm{~mm}$ individually, their combined breadth being double or more than the mean proximal dimension.

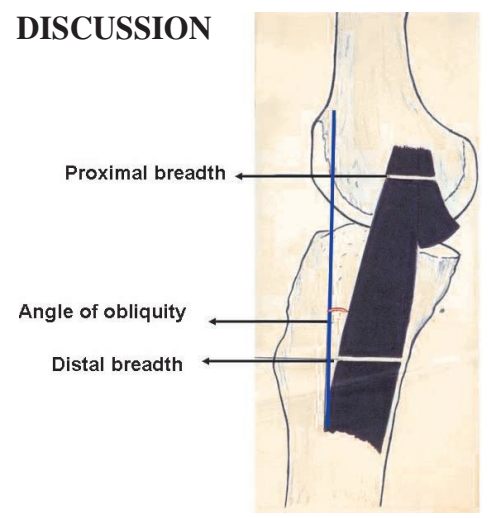

The anatomy of the medial collateral ligament complex consists of three passive restraining structures (Robinson et al., 2005). The structural properties of the different components of the medial collateral ligament complex indicate possible functional significance (Robinson et al., 2005). Anatomical observations have shown how different fiber bundles appear to be recruited in internal and external rotation (Robinson et al., 2004).

Bone-ligament-bone preparations have been used to establish the effect of limb immobilization on the ultimate strength of medial collateral ligament in animals (Laros et al., 1971; Woo et al., 1987). They showed that immobilization caused resorption and weakening of the ligament attachment sites. The firm attachment of the medial collateral ligament to the medial meniscus is of considerable significance because injury to the medial collateral ligament frequently results in concomitant injury to the medial meniscus (Moore, 1992). Medial collateral ligament at young age will have enhanced risk of avulsion at the bone - toligament interface while in older age groups injuries are more common along the length of the ligament. This is due in large part to the strength and stiffness properties of medial collateral ligament with respect to age (Woo et al. 1986).

The observations recorded in the present study shows that there is not much variation in dimension between the two limbs of any one cadaver. There was also not any significant difference between data in the two sexes. The additional parameter of measuring the angle of obliquity may aid us, with further series of comparative dissections, the effect of any, between the habitual squatting stresses the joint is subjected to in certain ethnic groups. This information might serve as the basis for future biomechanical studies to investigate the contribution of medial collateral ligament to joint stability. The variation in the upper attachment through bifurcation needs further detailed study in larger series.
RANADE, A. V.; RAI, R.; PRABHU, L. V.; KUMARAN, M. \& KUMAR, A. Estudio morfométrico del ligamento colateral tibial. Int. J. Morphol., 24(4):677-678, 2006.

RESUMEN: El ligamento colateral tibial, por virtud de su longitud, inserciones y esfuerzos biomecánicos, está más propenso a lesiones. Un análisis sistemático de las dimensiones y variaciones de este ligamento se presentan en este artículo. El decrecimiento del énfasis de la Anatomía como un ramo preclínico y la falta de cadáveres nos movieron a disminuir las horas de disección. Así, en nuestra opinión, los datos anatómicos son progresivamente más escasos. Con el propósito de registrar las características morfológicas macroscópicas del ligamento colateral tibial, realizamos una serie de disecciones.

\section{PALABRAS CLAVE: Ligamento colateral tibial; Anatomía}

\section{REFERENCES}

Brantigan, O. C. \& Voshell, A. F. The tibial collateral ligament: Its function, its bursae and its relation to the medial meniscus. $J$. of Bone and Joint Surg., 25:121-31, 1943.

Hammer, W. I. Medial collateral ligament sprain- Part I. Dynamic Chiropractic, 1991.

Laros, G. S.; Tipton, C. M. \& Cooper, R. R. Influence of physical activity on ligament insertion in the knees of dogs. J. of Bone and Joint Surg., 53 A:275-86, 1971.

Moore, K. L. Clinically oriented anatomy. $3^{\text {rd }}$ Ed. Williams \& Wilkins, Baltimore, 1992. pp. 481-2.

Palmer, I. On the injuries to the ligaments of the knee joint. Acta Orthopaedics Scandinavica Suppl., 5:283, 1938.

Robinson, J. R.; Bull, A. M. J. \& Amis, A. A. Structural properties of the medial collateral ligament complex of the human knee. J. of Biomechanics, 38:1067-74, 2005.

Robinson, J. R.; Sanchez- Ballester, J.; Bull, A. M. J.; Thomas, R. de W. \& Amis, A. A. The posteromedial corner revisited: An anatomical description of the passive restraining structures of the medial aspect of human knee. J. of Bone and Joint Surg., 86B:674-81, 2004.

Standring, S.; Ellis, H.; Healy, J.; Johnson, D. \& Williams, A. Eds. Grays Anatomy: Anatomical basis of clinical practice. $39^{\text {th }} \mathrm{Ed}$. Elsevier Churchill Livingstone, 2005. p. 1479.

Woo, S. L.; Gomez, M. A.; Sites, T. J.; Newton, P. O.; Orlando, C. A. \& Akeson, W. H. The biomechanical and morphological changes in the medial collateral ligament of the rabbit after immobilization and remobilization. J. of Bone and Joint Surg., 69 A:1200-11, 1987.

Woo, S. L. Y. et al. Tensile properties of medial collateral ligament as a function of age. J. Orthop. Res., 4:133-41, 1986.

Correspondence to:

Anu V. Ranade,

Department of Anatomy, CBS, KMMC, Bejai,

Mangalore, KarnataKa. 575004, INDDIA

Email:anuranade@yahoo.co.in 